\title{
Use of ammonium chloride to prevent urolithiasis in sheep
}

\author{
[Utilização do cloreto de amônio na prevenção de urolitíase em ovinos]
}

\author{
F.C. Navarro ${ }^{1}$, L.A.T. Bentin ${ }^{1}$, F. Bovino ${ }^{1}$, R.S. Baptista ${ }^{1}$,
} F.L.F. Feitosa ${ }^{2}$, J.R. Peiró ${ }^{2}$, L.C.N. Mendes ${ }^{2}$

\footnotetext{
${ }^{1}$ Aluno de pós-graduação - Faculdade de Medicina Veterinária - Universidade Estadual Paulista - Araçatuba, SP

${ }^{2}$ Faculdade de Medicina Veterinária - Universidade Estadual Paulista - Araçatuba, SP
}

\begin{abstract}
Urolithiasis has a high incidence among confined sheep. It is multifactorial and may cause economic damage. Our aim was to determine the capacity of urinary acidification using ammonium chloride in sheep. Twenty-five 3-month-old male sheep were confined and randomly divided into three groups; the G200 and G500 groups received $200 \mathrm{mg} / \mathrm{kg} / \mathrm{GW}$ and $500 \mathrm{mg} / \mathrm{kg} / \mathrm{GW}$ of ammonium chloride daily for 56 consecutive days, respectively, whereas the CG group did not receive ammonium chloride. Sampling times and clinical evaluation were performed weekly, starting from the $14^{\text {th }}$ day of confinement (M1 or immediately before administering ammonium chloride) until the $17^{\text {th }}$ day (M9) of the feedlot. Hemogasometry, biochemical examination of serum urea and creatinine concentration and ultrasound evaluation of the urinary tract were performed. The urinalysis indicated a higher incidence of ammonium magnesium phosphate crystals at the beginning of the study, showing a migration to urate crystal formation, mainly in the G500 group because of urinary acidification. No hemogasometric, serum biochemistry, ruminal fluid, or ultrasonographic changes were observed. Urinary acidification was achieved and maintained after M7 during the administration of ammonium chloride in the G500 group, but not in the other study groups.
\end{abstract}

Keywords: urinary lithiasis, ammonium chloride, urinalysis, hemogasometry

\section{RESUMO}

A urolitíase apresenta alta incidência em ovinos confinados, etiologia multifatorial, e pode causar prejuízo econômico. $O$ objetivo do presente estudo foi determinar a capacidade da acidificação urinária mediante o uso de cloreto de amônio em ovinos. Foram utilizados 25 ovinos de três meses de idade, confinados e divididos aleatoriamente em três grupos: grupo CG (controle) não recebeu cloreto de amônio; grupo G200 (200mg/kg/PV) recebeu cloreto de amônio por 56 dias consecutivos; grupo G500 $(500 \mathrm{mg} / \mathrm{kg} / \mathrm{PV}$ ) recebeu cloreto de amônio por 56 dias consecutivos, administrados diariamente por via oral. Os momentos $(M)$ de colheita de amostras e de avaliação clínica foram realizados com intervalo de sete dias, sendo M1 (imediatamente antes do cloreto de amônio), M2 (sete dias após) até M9, totalizando 70 dias de confinamento. Foram realizadas hemogasometria, concentração sérica de ureia e creatinina e avaliação ultrassonográfica do trato urinário. Na urinálise, houve uma maior incidência de cristais de fosfato amônio magnesiano no início do estudo, com migração para formação de cristais de urato, principalmente no G500, devido à acidificação urinária. Não houve alterações hemogasométricas, na bioquímica sérica, no líquido ruminal, ou alterações ultrassonográficas. A acidificação urinária foi obtida e mantida a partir do M7 durante a administração do cloreto de amônio no grupo G500, não ocorrendo nos outros grupos de estudo.

Palavras-chave: litíase urinária, cloreto de amônio, urinálise, hemogasometria

Recebido em 22 de junho de 2020

Aceito em 22 de abril de 2021

E-mail: fabio_navarro@uol.com.br 


\section{INTRODUCTION}

The incidence of obstructive urolithiasis in sheep is high, mainly when they are confined. Several studies have investigated this multifactorial condition, which causes economic damage, affects sheep's reproductive health, and may even lead to death (Guimarães et al., 2012), affecting primarily males because of anatomical reasons, whose complications may necessitate surgical treatment The main factors associated with lithogenesis are urinary stasis, dehydration, low fluid intake, alkaline urinary $\mathrm{pH}$, decreased urinary protective factors, and increased excretion of minerals in the urine, mainly due to an imbalance in the concentration of calculogenic components in feed, such as diets rich in protein, calcium, magnesium, or phosphorus, or even the intake of certain oxalate or silica-rich plants (Stewart et al., 1990).

Protective factors in the formation of urolithiasis (such as colloids) have limited capacity, and urinary stones form with the precipitation of solutes and aggregation of calculogenic components (Smith, 2006). Concentrate-rich and low-roughage diets could reduce rumination and lead to hyperconcentration and increased phosphorus excretion in the urine. Urinary stasis leads to the formation and aggregation of insoluble compounds and favors lithogenesis (Loretti et al., 2003). The formed nucleus promotes precipitation, aggregation, and concretion around it, increasing its volume and causing obstruction of the urinary tract (Radostits et al., 2000). Some authors, such as Ferreira (2009); Ferreira et al (2014) used ammonium chloride and vitamin C (ascorbic acid) for urinary acidification, leading to conflicting results and even inducing urinary calculus formation. Therefore, the objective of this work was to evaluate the capacity of urinary acidification in sheep using ammonium chloride analyzed through urinalysis.

\section{MATERIAL AND METHODS}

According to a model developed by Ferreira et al. (2014), 25 confined, 3-month-old weighing an average of $13 \mathrm{~kg}$ male sheep (breeds: Dorper, Santa Inês, and Morada Nova) were randomly divided into three groups, according breeds and weight. For 56 consecutive days, each sheep in the G200 ( $=10)$ and G500 $(n=10)$ groups was orally administered $200 \mathrm{mg} / \mathrm{Kg} / \mathrm{GW}$ and $500 \mathrm{mg} / \mathrm{Kg} / \mathrm{GW}$ of ammonium chloride per day, respectively; sheep in the $\mathrm{CG}(\mathrm{n}=5$; control) group were not administered ammonium chloride. All animals were dewormed (Zolvix, Novartis Saúde Animal) and vaccinated against clostridiosis (Glanvac 6, Fort Dodge Saúde Animal, Campinas-SP). During the adaptation period (first 14 days) of the total 70-day confinement, they were kept in a common environment, under identical humidity, temperature, and light conditions, with daily cleaning of the place. The area of the site was $730 \mathrm{~m} 2$, which is $29.2 \mathrm{~m} 2$ per animal. On Tuesdays, we performed a physical examination and weighed all animals and ammonium chloride that would be administered during the week.

On Wednesdays, urine and blood samples were collected from all animals, kept in cold storage, and immediately delivered to the laboratory for analysis. On Thursdays, the urinary system of all animals was assessed using ultrasound. Each day, ammonium chloride was diluted in about $20 \mathrm{~mL}$ of distilled water and orally administered (based on weight) to each sheep in the G200 and G500 groups. The CG animals only received $20 \mathrm{~mL}$ of distilled water. Total feed for sheep was used (Table 1). Mineral salt was not provided. Water was supplied in two troughs, ad libitum, from the company SAMAR (Soluções Ambientais de Araçatuba).

The feed was sampled according to the guidance of the analysis company. The DM was subjected to chemical analysis and characterized by $16.19 \%$ crude protein, $3.27 \%$ ether extract, $15.67 \%$ crude fiber, and $5.87 \%$ minerals. Further analysis ofminerals in the total ration identified $12900 \mathrm{ppm}$ and $2400 \mathrm{ppm}$ DM of calcium and phosphorus (5:1 ratio), respectively. The average daily feed consumption was $3 \%$ of body weight (average: $1.15 \mathrm{~kg}$ of total daily feed per animal). The incidence of urolithiasis was evaluated in the three experimental groups (G200, G500, and CG) throughout the experiment, according to the following protocol, divided into moments (M) shown in Figure 1.

Clinical evaluations (rectal temperature [RT], ruminal movement $[\mathrm{RM}]$, heart rate $[\mathrm{HR}]$, and respiratory rate $[R R])$, blood and urine tests, and ultrasound were performed weekly between 7-9 am. The project was approved by the Ethics 
Committee on Animal Experimentation at the Universidade Estadual Paulista Faculty of Veterinary Medicine of Araçatuba, Brazil, Process FOA no. 2015-00635 - CEUA. Weekly urine collection was obtained through natural or forced urination by interrupting breathing (occlusion of the nostrils for 10-20 seconds), as described by Garcia-Navarro (1996). The samples were placed in sterile flasks, stored in a refrigerator $\left(4^{\circ} \mathrm{C}-8^{\circ} \mathrm{C}\right)$, and immediately sent for urinalysis. Volume (mL), color, odor, appearance, density, $\mathrm{pH}$, proteins, glucose, acetone, urobilinogen, occult blood, and bile salts were evaluated using a reagent strip $\left(\right.$ Combur Test ${ }^{\circledR}$, Roche Diagnóstica Brasil Ltda. São Paulo, Brazil). The urine sample $(5 \mathrm{~mL})$ was centrifuged at $7000 \times \mathrm{g}$ for fivemin, discarding the supernatant, leaving $0.5 \mathrm{~mL}$ of urine for the analysis of the sediment, including identification of urinary tract cells, red blood cells, leukocytes, cylinders, crystals, bacteria, sperm, and mucus, using a common optical microscope $(400 \times$ magnification).
Table 1. Table contents total feed for sheep was used feed analysis result (ARASOLO www.arasolo.com.br - N 16.20507)

\begin{tabular}{lc}
\multicolumn{2}{c}{ Non-Protein Nitrogen } \\
\hline Contents & $\%$ \\
Dry Matter & 90.71 \\
Humidity & 9.29 \\
Crude Protein & 16.19 \\
Ether extract & 3.27 \\
Mineral Matter & 5.87 \\
Crude Fiber & 15.67 \\
ENN & 49.71 \\
FDN & 29.28 \\
FDA & 17.84 \\
Total Nitrogen & 2.59 \\
NP Nitrogen & 0.28 \\
Sol Nitrogen & 0.33 \\
NIDN & 0.46 \\
NIDA & 0.27 \\
Phosphorus & 0.24 \\
Calcium & 1.29 \\
Magnesium & 0.17 \\
Sodium & 0.85 \\
Potassium & 1.00 \\
\hline
\end{tabular}

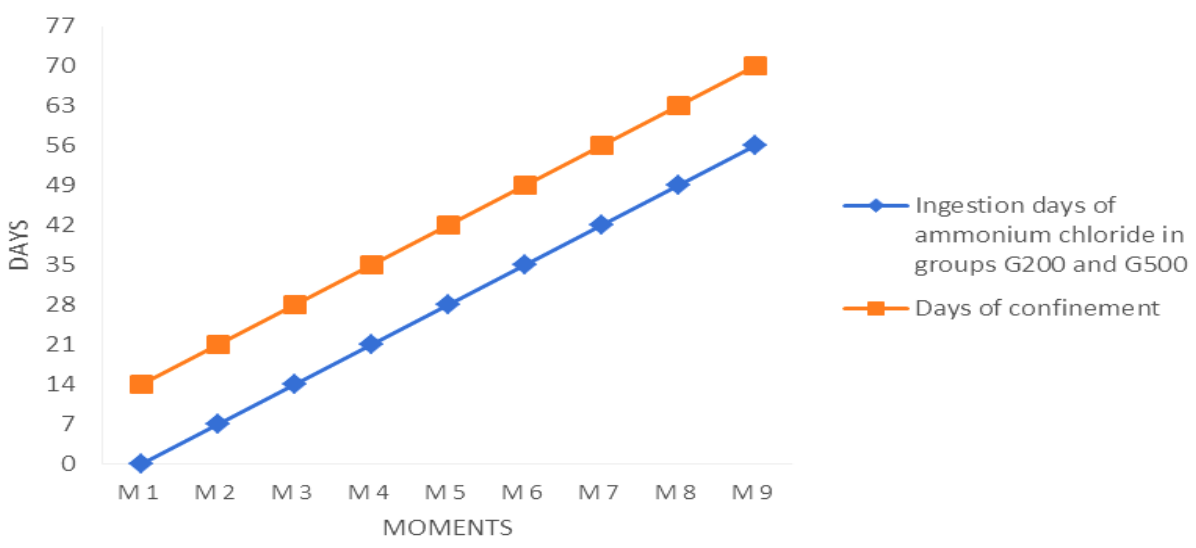

Figure 1. Ingestions moments of ammonium chloride with respective days of confinement.

One milliliter of blood from the jugular vein was collected weekly in a previously heparinized polyethylene syringe (Monovette $2 \mathrm{~mL} \mathrm{LH}$, Sarstedt AG \& Co., Germany) coupled with a $25 \mathrm{~mm} \times 7 \mathrm{~mm}$ needle (luer lock system), sealed with a rubber, and stored at $4^{\circ} \mathrm{C}-8^{\circ} \mathrm{C}$. Hemogasometric examination was performed immediately using a device calibrated at $39^{\circ} \mathrm{C}$ (Radiometer ABL 800 Basic, Blood gas analyzer, Radiometer, Denmark). The values of $\mathrm{pO}_{2}, \mathrm{pCO}_{2}, \mathrm{pH}, \mathrm{HCO}^{-3}, \mathrm{TCO}_{2}, \mathrm{sO}_{2}$, and base excess (BE) were measured. To perform the biochemical examination of serum urea and creatinine concentrations, blood was drawn from the jugular vein into tubes without anticoagulant, with vacuum and clot-activating gel (Serum gel Z / 4.9mL, Monovette, Sarstedt AG \& Co., Germany), using a $25 \mathrm{~mm} \times 7 \mathrm{~mm}$ needle at different times. The samples were centrifuged at $2000 \times \mathrm{g}$ for $10 \mathrm{~min}$ and automatically analyzed using an enzymatic-colorimetric method and a kinetic-colorimetric method to determine urea and creatinine concentrations, respectively, using 
a spectrophotometer (LABMAX 240, LABTEST Diagnóstica, São Paulo, Brazil).

A portable ultrasound device (DP-2200 Vetmindray) with a convex transducer and 5.0 $\mathrm{MHz}$ frequency was used on a veterinary stretcher. After manual restraint, the animal was kept in a supine position for evaluating the kidneys, and dorsal position for assessing the bladder and with abducted pelvic members (Scott, 2013). If urethral obstruction was suspected, it was further evaluated. A conductive gel was used while probing for better evaluation. Images were recorded and analyzed at the time of the procedure and subsequently rigorously reassessed. After the study period, one animal was randomly sampled from each group (3 in total) and necropsied with a focus on the urinary tract.

Data from physical examination, urinalysis, blood gas analysis, and serum biochemistry were analyzed using Software Action 2.7 (Portal Action, Estaticamp). A p-value of less than 0.05 was considered statistically significant. Continuous variables were analyzed using the Kruskal-Wallis test to identify differences between groups within the same harvest time (M), and statistically significant differences were verified using Dunn's post hoc test. Medians were assessed using the Friedman test over nine moments (M1-M9) for physical examination (RT, RM, HR, and RR), urinalysis (volume, density, and $\mathrm{pH})$, blood gas analysis $\left(\mathrm{pCO}_{2}, \mathrm{pH}\right.$,
$\mathrm{HCO}^{-3}, \mathrm{TCO}_{2}, \mathrm{BE}$ ), and serum biochemistry (urea and creatinine) parameters. Categorical variables that were assessed using the chisquared test included urinalysis (color, appearance, and protein) and blood test (bacteria, crystals, cylinders, mucus, red blood cells, and leukocytes) parameters. Only descriptive analysis was performed for ultrasound findings.

\section{RESULTS AND DISCUSSION}

Urinary $\mathrm{pH}$ is extremely important for inducing or protecting urolithiasis. Alkaline urine favors the formation of calculi, frequently consisting of carbonate, amorphous phosphate, calcium phosphate (apatite), and magnesium triple ammonium phosphate (struvite) because the diet of animals in intensive management systems is rich in grains containing magnesium and phosphorus (Radostits et al., 2000). In the G500 group with ammonium chloride administration, there was urinary acidification at M7, which was different from the other groups that maintained a basic $\mathrm{pH}$. At a given moment, no statistical difference was observed between groups; however, there was a difference between moments, especially in G500 (Table 2). No change in the physical examination was observed between animals who received or did not receive ammonium chloride, demonstrating safety in its administration until the dosage of $500 \mathrm{mg} / \mathrm{kg} / \mathrm{GW}$ per day, with few differences between moments within the same group.

Table 2. Means $(m)$, standard deviations $(s)$ and medians $(M d)$ of urine $\mathrm{pH}$ of sheep during moments $(\mathrm{M})$ in the experimental groups (CG, G200 and G500)

\begin{tabular}{lcccccc}
\hline \multirow{2}{*}{ Moments } & \multicolumn{2}{c}{$\mathrm{CG}(\mathrm{n}=5)$} & \multicolumn{2}{c}{$\mathrm{G} 200(\mathrm{n}=10)$} & \multicolumn{2}{c}{$\mathrm{G} 500(\mathrm{n}=10)$} \\
& $m \pm s$ & $M d$ & $m \pm s$ & $M d$ & $m \pm s$ & $M d$ \\
\hline M1 & $9.0 \pm 0.00$ & $9.0^{\mathrm{Aa}}$ & $8.7 \pm 0.95$ & $9.0^{\mathrm{BCa}}$ & $8.6 \pm 1.26$ & $9.0^{\mathrm{BCDEa}}$ \\
M2 & $8.5 \pm 1.11$ & $9.0^{\mathrm{Aa}}$ & $8.1 \pm 1.00$ & $8.0^{\mathrm{Aa}}$ & $7.0 \pm 1.70$ & $6.8^{\mathrm{BFKLQ}}$ \\
M3 & $9.0 \pm 0.00$ & $9.0^{\mathrm{Aa}}$ & $9.0 \pm 0.00$ & $9.0^{\mathrm{DEa}}$ & $8.5 \pm 1.30$ & $9.0^{\text {FGHIJa }}$ \\
M4 & $9.0 \pm 0.00$ & $9.0^{\mathrm{Aa}}$ & $6.3 \pm 1.70$ & $5.5^{\mathrm{BDFGa}}$ & $6.3 \pm 1.49$ & $6.0^{\mathrm{AGPUVa}}$ \\
M5 & $9.0 \pm 0.00$ & $9.0^{\mathrm{Aa}}$ & $8.7 \pm 0.90$ & $9.0^{\mathrm{FHa}}$ & $8.6 \pm 1.30$ & $9.0^{\mathrm{LMNOUa}}$ \\
M6 & $9.0 \pm 0.00$ & $9.0^{\mathrm{Aa}}$ & $9.0 \pm 0.00$ & $9.0^{\mathrm{GIa}}$ & $8.3 \pm 1.49$ & $9.0^{\text {PQRSTVa}}$ \\
M7 & $8.1 \pm 0.41$ & $8.0^{\mathrm{Aa}}$ & $8.2 \pm 0.35$ & $8.5^{\mathrm{Aa}}$ & $6.6 \pm 1.05$ & $6.2^{\mathrm{CHMRa}}$ \\
M8 & $8.1 \pm 0.22$ & $8.0^{\mathrm{Aa}}$ & $7.4 \pm 0.95$ & $7.7^{\mathrm{CEHIa}}$ & $6.2 \pm 1.06$ & $6.0^{\text {DINSa }}$ \\
M9 & $8.7 \pm 0.62$ & $9.0^{\mathrm{Aa}}$ & $8.5 \pm 0.54$ & $9.0^{\mathrm{Aa}}$ & $6.3 \pm 1.80$ & $5.0^{\text {EJOTa }}$ \\
\hline
\end{tabular}

${ }^{a b c}$ Different lowercase letters indicate difference between groups at each moment.

${ }^{\mathrm{ABC}}$ Different capital letters indicate difference between moments in each group.

Ferreira et al. (2014) administered a dose of $400 \mathrm{mg} / \mathrm{kg} / \mathrm{GW}$ in feed, and observed a decrease in the urinary $\mathrm{pH}$ from the second day; however, the difference in administering the feed should be noted. In our study, ammonium chloride was daily administered individually and orally in 
known amounts and varied based on individual weight. Another study, however, tested doses of 200,400 , and $500 \mathrm{mg} / \mathrm{kg} /$ day orally in eight goats; there was no metabolic acidosis or impalability (Mavangira et al., 2010). The $200 \mathrm{mg} / \mathrm{kg} /$ day dose did not acidify urine, $400 \mathrm{mg} / \mathrm{kg} /$ day promoted acidic urine for a period of less than $20 \mathrm{~h}$, and the larger dose was effective for more than 30 hours, thus concluding that the ideal dose should be between 400$500 \mathrm{mg} / \mathrm{kg}$ similar to our study.

To observe changes in the urine only due to ammonium chloride, mineral salt must not be administered to the animals, because it can be confusion factor, similar to a previous study by Ferreira et al. (2014), whose animals had an acidic $\mathrm{pH}$ from the beginning of the study. If dietary mineral salt is used, it must be gradually increased to stimulate water intake and increased urinary volume. It should be mixed with feed, and limited to about $3 \%-5 \%$ of daily DM (Stratton-Phelps and House, 2004) for no interpretation to occur. However, other studies have suggested that mineral salt must not be supplemented, cause there is no change in the urinary $\mathrm{pH}$ and lithogenesis (Riet-Correa et al., 2008).

As an alternative to sodium chloride supplementation (the main component of mineral salt), ammonium chloride can be used in $0.5 \%$ $1 \%$ of daily $\mathrm{DM}$, leading to a reduction in $\mathrm{pH}$, changing calculogenic minerals more soluble in the urine through the promotion of an anionic diet (Stratton-Phelps and House, 2004). Ammonium chloride is converted into urea and hydrochloric acid in the liver, leading to a greater release of $\mathrm{H}^{+}$ions into the bloodstream, which is excreted into renal tubules. Acidemia is thus compensated by the buffering effect of serum bicarbonate, leading to the formation of an unstable acid (carbonic acid), which dissociates into carbonic gas, expelled through breathing and formation of water. The remaining chloride ions and urea cause aciduria, increased water intake, osmotic diuresis, and eliminated in the form of sodium chloride (Smith, 2006; Pugh and Baird, 2012).

Animals with extensive management that feed on plants rich in oxalate and silica are predisposed to the formation of stones because of these substances. Studies on ammonium chloride in the diet of ruminants observed that the group with supplementation of $1 \%$ of live weight $(\mathrm{GW})$ in diet or even with additional calcium supplementation, did not present urolithiasis, concluding that ammonium chloride acts as a protective factor, together with an adequate association of Calcium and Phosphorus (2:1 ratio) (Stewart et al., 1991). Our study had a Ca$\mathrm{P}$ ratio of 5:1; however, with no evidence of lithiasis during the study.

Crystals showed no significant difference in our study. The presence and type of crystals and the interference of the urinary medium (acid or alkaline), can determine the formation of lithiasis (Garcia-Navarro, 1996). Protein and salt-rich diets can influence the type of calculus. Struvite stones are the most common type in sheep, primarily because of an alkaline $\mathrm{pH}$, followed by carbonate and silicate crystals. In the first moments of this study, there was a predominance of struvite crystal, subsequently replaced by those of urates (G500 group) and amorphous phosphate in the other groups (Jones et al., 2017) (Table 3). A study (Ferreira et al., 2014) obtained $27 \%$ and $8 \%$ crystals over time in CG and ammonium chloride groups, respectively, concluding that ammonium chloride has a protective effect on the formation of crystals, although crystals formed in all groups. However, another study (Mavangira et al., 2010) did not find an association between ammonium chloride supplementation and the presence of crystalluria, although, they observed a greater quantity of crystals (triple phosphate and calcium oxalate) in animals that did not receive ammonium chloride, corroborating our findings.

High-protein diets ( $>20 \% \mathrm{GW})$ can lead to renal overload and proteinuria; our diet had about $16.19 \% \mathrm{CP}$, making such issues less likely. Furthermore, the average weight gain remained within the normal range (Figure 3) in all groups, with no significant difference, demonstrating that the use of a balanced diet with or without the use of ammonium chloride did not interfere with weight gain. Similar to Ferreira et al. (2014), we demonstrated that using ammonium chloride did not interfere in animal development, with an average feed intake of $1.15 \mathrm{~kg} / \mathrm{d} / \mathrm{animal}$, similar found by them $(1.2 \mathrm{~kg} / \mathrm{d} /$ animal $)$. 
Table 3. Presence and type of urinary crystals found along moments M1, M2, M5 and M6 in sheep subjected to ingestion of ammonium chloride

\begin{tabular}{|c|c|c|c|c|c|c|c|c|c|c|c|c|}
\hline \multirow{3}{*}{ Urinary crystals } & \multicolumn{12}{|c|}{ Moments } \\
\hline & \multicolumn{3}{|c|}{ M1 } & \multicolumn{3}{|c|}{ M2 } & \multicolumn{3}{|c|}{ M5 } & \multicolumn{3}{|c|}{ M6 } \\
\hline & Control & G200 & G500 & Control & G200 & G500 & Control & G200 & G500 & Control & G200 & G500 \\
\hline Uric Ácid & 0 & 1 & 0 & 0 & 1 & 1 & 0 & 0 & 0 & 0 & 0 & 4 \\
\hline Struvite & 0 & 1 & 2 & 1 & 1 & 2 & 1 & 1 & 0 & 1 & 1 & 1 \\
\hline Amorphous Phosphate & 0 & 0 & 0 & 1 & 1 & 0 & 1 & 1 & 0 & 3 & 2 & 0 \\
\hline Oxalate & 0 & 1 & 0 & 1 & 0 & 1 & 0 & 0 & 0 & 0 & 0 & 0 \\
\hline
\end{tabular}

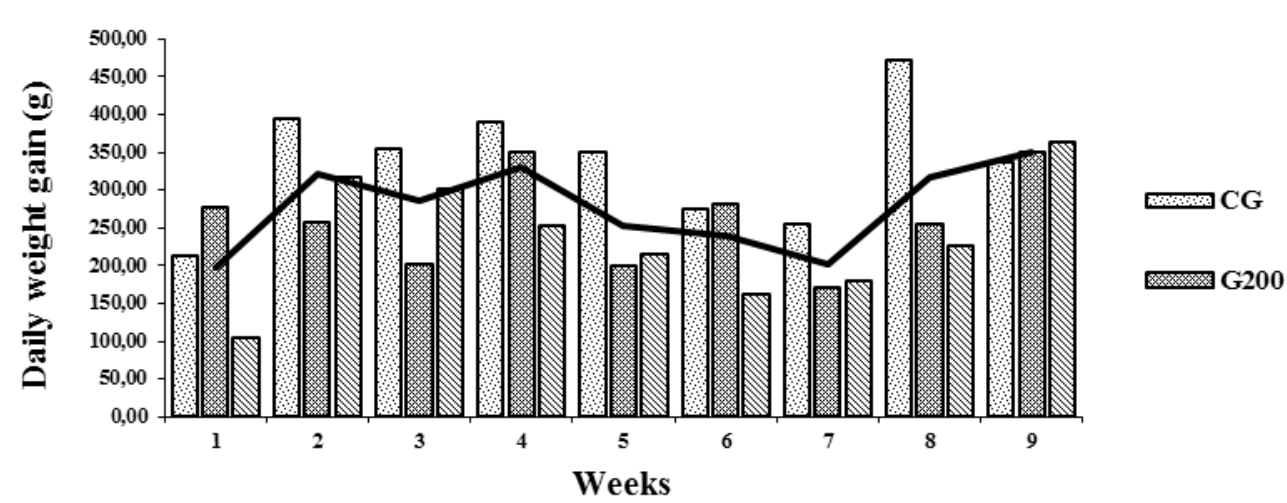

Figure 3. Average daily weight gain (g) over moments (weeks) evaluated in sheep in CG, G200, G500 and general average.

All hemogasometric parameters analyzed $\left(\mathrm{pCO}_{2}\right.$, $\mathrm{pH}, \mathrm{HCO}^{-3}, \mathrm{TCO}_{2}$, and $\mathrm{EB}$ ) showed no statistical difference among groups, differing within the same group (G200 and G500) at different times, although staying within the normal range for sheep, according to Ortolani (2003). Similar to our studies, Mavangira et al. (2010) and Jones et al. (2009) demonstrated urinary acidification without metabolic acidosis in animals. Ferreira et al. (2014) demonstrated compensated metabolic acidosis in the group using ammonium chloride with a dose of $400 \mathrm{mg} / \mathrm{kg} / \mathrm{day}$ in feed, possible because of the use of a high-protein diet, mineral salt, and Ca-P imbalance in diet since their animals had started the study with an acid $\mathrm{pH}$, which is unusual for sheep with intense aciduria. Excessive urinary acidification should be avoided because of the risk of decreased feed intake and the risk of metabolic acidosis (Singh et al., 2007); (Las et al., 2007) and (Macleay et al., 2004).

Rumen lactic acidosis can lead to metabolic acidosis, characterized by a decrease in $\mathrm{pH}$ and $\mathrm{HCO}^{-3}$ (Cornelius and Kaneko, 2008). An animal in the G500 group died at M7 due to enteritis and pneumonia. A single sample of ruminal fluid was collected in the morning for $\mathrm{pH}$ analysis using a por Table peameter by passing a probe orally to the rumen for aspirated ruminal fluid before administering ammonium chloride. No significant changes in the ruminal fluid were observed during the comparison of the three groups at Moment 9 (M9), demonstrating the safety of administering up to $500 \mathrm{mg} / \mathrm{kg} / \mathrm{GW}$ per day (Table 4). Thus, we believe that the death of this animal should not have been caused by the use of ammonium chloride

Table 4. Ruminal pH values collected in M9 in experimental groups (CG, G200 and G500) of all animals

\begin{tabular}{ccccccc}
\multirow{2}{*}{ Moments } & \multicolumn{2}{c}{$\mathrm{CG}(\mathrm{n}=5)$} & \multicolumn{2}{c}{$\mathrm{G} 200(\mathrm{n}=10)$} & \multicolumn{2}{c}{$\mathrm{G} 500(\mathrm{n}=10)$} \\
\cline { 2 - 7 } & $m \pm s$ & $M d$ & $m \pm s$ & $M d$ & $m \pm s$ & $M d$ \\
\hline M9 & $6.8 \pm 0.44$ & $7.0^{\mathrm{Aa}}$ & $6.5 \pm 0.52$ & $6.5^{\mathrm{Aa}}$ & $6.22 \pm 0.44$ & $6.00^{\mathrm{Aa}}$ \\
\hline
\end{tabular}

$\overline{\mathrm{abc}}$ Different lower-case letters indicate difference between groups at each moment.

${ }^{\mathrm{ABC}}$ Different capital letters indicate difference between moments in each group. 
Urea concentrations remained slightly above the normal limits defined for sheep (Cornelius and Kaneko, 2008). Although they did not differ among study groups at each moment, differences between moments within the same group were observed, especially at moments M3 and M4 in the G200 and G500 groups (Table 5). However, no animal showed signs of uremic syndrome. Our findings corroborate those of Ferreira et al. (2014), who showed a slightly higher level of urea, with no symptoms in animals in any group (Jones et al., 2009).

Table 5. Means $(m)$, standard deviations $(s)$ and medians $(M d)$ of serum urea $(\mathrm{mg} / \mathrm{dL})$ in sheep, at different times of harvest in experimental groups (CG, G200 and G500)

\begin{tabular}{lcccccc}
\hline \multirow{2}{*}{ Moments } & \multicolumn{2}{c}{$\mathrm{CG}(\mathrm{n}=5)$} & \multicolumn{2}{c}{$\mathrm{G} 200(\mathrm{n}=10)$} & \multicolumn{2}{c}{$\mathrm{G} 500(\mathrm{n}=10)$} \\
\cline { 2 - 7 } & $m \pm s$ & $M d$ & $m \pm s$ & $M d$ & $m \pm s$ & $M d$ \\
\hline M1 & $44.2 \pm 5.89$ & $41.0^{\mathrm{Aa}}$ & $40.3 \pm 12.73$ & $39.0^{\mathrm{Ba}}$ & $40.2 \pm 5.31$ & $39.5^{\mathrm{Aa}}$ \\
M2 & $49.4 \pm 8.38$ & $49.0^{\mathrm{Aa}}$ & $49.9 \pm 12.06$ & $49.5^{\mathrm{Aa}}$ & $40.2 \pm 6.12$ & $41.5^{\mathrm{Ba}}$ \\
M3 & $56.8 \pm 8.10$ & $60.0^{\mathrm{Ba}}$ & $58.5 \pm 9.36$ & $55.5^{\mathrm{BCDa}}$ & $51.7 \pm 7.34$ & $51.0^{\mathrm{BCDa}}$ \\
M4 & $35.0 \pm 7.87$ & $37.0^{\mathrm{Ba}}$ & $34.1 \pm 8.03$ & $32.0^{\mathrm{CEFGHa}}$ & $31.0 \pm 6.32$ & $31.5^{\mathrm{CEFa}}$ \\
M5 & $42.4 \pm 5.89$ & $41.0^{\mathrm{Aa}}$ & $52.3 \pm 16.02$ & $48.5^{\mathrm{Ea}}$ & $46.7 \pm 6.03$ & $47.5^{\mathrm{Ea}}$ \\
M6 & $46.4 \pm 6.18$ & $45.0^{\mathrm{Aa}}$ & $51.6 \pm 6.83$ & $49.5^{\mathrm{Fa}}$ & $46.3 \pm 6.58$ & $47.0^{\mathrm{Fa}}$ \\
M7 & $45.2 \pm 4.54$ & $47.0^{\mathrm{Aa}}$ & $47.2 \pm 8.68$ & $45.6^{\mathrm{Da}}$ & $42.1 \pm 3.90$ & $43.0^{\mathrm{Da}}$ \\
M8 & $46.6 \pm 6.18$ & $47.0^{\mathrm{Aa}}$ & $53.8 \pm 8.39$ & $49.0^{\mathrm{Ga}}$ & $41.7 \pm 3.86$ & $44.0^{\mathrm{Aa}}$ \\
M9 & $47.4 \pm 10.54$ & $44.0^{\mathrm{Aa}}$ & $57.5 \pm 20.46$ & $70.0^{\mathrm{Ha}}$ & $48.5 \pm 5.75$ & $48.0^{\mathrm{Aa}}$ \\
\hline
\end{tabular}

${ }_{\text {abc }}$ Different lower-case letters indicate difference between groups at each moment.

${ }^{\mathrm{ABC}}$ Different capital letters indicate difference between moments in each group.

Despite observing below normal creatinine values (Cornelius and Kaneko, 2008) (Table 6), there was no statistically significant difference among groups; only within-group variations were observed without clinical significance, similar to the findings of Ferreira et al. (2014) and Lima et al. (2015). Creatinine is a more reliable renal failure marker than urea; however, it is altered only when more than half of the nephrons are affected (Garcia-Navarro, 1996). When there was a low urinary obstruction or even bilateral high urinary obstruction, there was an increase in urea and creatinine levels, something that did not occur during the present study. Analyzing both urea and creatinine allows us to exclude renal dysfunction during the experiment, something that is already expected since there were no signs of urolithiasis.

Table 6. Means $(m)$, standard deviations $(s)$ and medians $(M d)$ of serum creatinine $(\mathrm{mg} / \mathrm{dL})$ in sheep, at different moments of harvest in experimental groups (CG, G200 and G500)

\begin{tabular}{lcccccc}
\multirow{2}{*}{ Moments } & \multicolumn{2}{c}{$\mathrm{CG}(\mathrm{n}=5)$} & \multicolumn{2}{c}{$\mathrm{G} 200(\mathrm{n}=10)$} & \multicolumn{2}{c}{$\mathrm{G} 500(\mathrm{n}=10)$} \\
\cline { 2 - 7 } & $m \pm s$ & $M d$ & $m \pm s$ & $M d$ & $m \pm s$ & $M d$ \\
\hline M1 & $0.71 \pm 0.14$ & $0.76^{\mathrm{BCa}}$ & $0.76 \pm 0.09$ & $0.75^{\mathrm{BCDa}}$ & $0.70 \pm 0.07$ & $0.72^{\mathrm{BCDa}}$ \\
M2 & $0.63 \pm 0.08$ & $0.63^{\mathrm{Aa}}$ & $0.70 \pm 0.09$ & $0.67^{\mathrm{EFa}}$ & $0.64 \pm 0.06$ & $0.64^{\mathrm{Ea}}$ \\
M3 & $0.51 \pm 0.06$ & $0.52^{\mathrm{Aa}}$ & $0.60 \pm 0.13$ & $0.60^{\mathrm{BGa}}$ & $0.55 \pm 0.06$ & $0.56^{\mathrm{Fa}}$ \\
M4 & $0.73 \pm 0.11$ & $0.71^{\mathrm{DEa}}$ & $0.80 \pm 0.09$ & $0.79^{\mathrm{GHIJ}}$ & $0.73 \pm 0.06$ & $0.74^{\mathrm{BFGHa}}$ \\
M5 & $0.41 \pm 0.06$ & $0.41^{\mathrm{BDa}}$ & $0.48 \pm 0.09$ & $0.49^{\mathrm{CEHILa}}$ & $0.43 \pm 0.06$ & $0.43^{\mathrm{CEGIa}}$ \\
M6 & $0.48 \pm 0.04$ & $0.51^{\mathrm{CEa}}$ & $0.56 \pm 0.10$ & $0.56^{\mathrm{DFIa}}$ & $0.57 \pm 0.03$ & $0.57^{\mathrm{DHa}}$ \\
M7 & $0.57 \pm 0.07$ & $0.59^{\mathrm{Aa}}$ & $0.64 \pm 0.09$ & $0.64^{\mathrm{CJa}}$ & $0.60 \pm 0.04$ & $0.61^{\text {Aa }}$ \\
M8 & $0.61 \pm 0.07$ & $0.62^{\mathrm{Aa}}$ & $0.69 \pm 0.08$ & $0.68^{\mathrm{Ka}}$ & $0.63 \pm 0.09$ & $0.64^{\text {Aa }}$ \\
M9 & $0.63 \pm 0.07$ & $0.63^{\mathrm{Aa}}$ & $0.69 \pm 0.10$ & $0.71^{\mathrm{La}}$ & $0.68 \pm 0.03$ & $0.68^{\text {Ia }}$ \\
\hline
\end{tabular}

${ }_{\mathrm{abc}}$ Different lower-case letters indicate difference between groups at each moment.

${ }^{A B C}$ Different capital letters indicate difference between moments in each group.

No group showed evidence of lithiasis or its complications during ultrasound examination, probably because of the balanced feed and absence ofmineral salt supplementation. Images of the kidneys and urinary tracts were obtained within normal limits, as proposed by Scott (2013). Ferreira et al. (2014) found bladder stones and sediments, dilation of the renal pelvis, and bladder thickening, in opposition to our studies. Necroscopic examination of the urinary 
system of sheep in the three groups did not show lithiasis or its complications. This is in contrast with the findings reported by Ferreira et al. (2014), that showed nephrolithiasis, hydronephrosis, loss of cortical-medullary definition, and renal hemorrhage more frequently in the control group. These observations can possibly be explained by the use ofmineral salt, a smaller and non-individualized dose of ammonium chloride, and a high-protein diet in their study. We supposed that our findings occurred because of a possible protective effect of ammonium chloride against lithogenesis.

\section{CONCLUSIONS}

Urinary acidification was achieved and maintained in the G500 group, mainly after M7, compared to the CG and G200 groups. There were no changes in the physical examination parameters, urea and creatinine concentrations, and blood gas analysis, demonstrating the safety of the studied dose. Our experimental model did not lead to the production of uroliths, as previously obtained by another previous studies.

\section{REFERENCES}

CORNELIUS, C.E.; KANEKO, J.J. Clinical biochemistry of domestic animals. San Diego: Academic Press., 2008. 936p.

FERREIRA, D. Avaliação da acidificação urinária em ovinos com a utilização de três tratamentos. 2009. 108f. Dissertação (Mestrado em Medicina Veterinária) - Faculdade de Medicina Veterinária e Zootecnia de Botucatu, Universidade Estadual Paulista, SP.

FERREIRA， D.O.L.; SANTAROSA， B.P.; DIAS, P.; SACCO, S.R. et al. Efeito da suplementação de cloreto de amônio sobre os equilíbrios eletrolítico e ácido-básico e o pH urinário de ovinos confinados. Pesqui. Vet. Bras., v.34, p.797-804, 2014.

GARCIA-NAVARRO, C. Manual de urinálise veterinária. São Paulo: Varela,1996. 96p.

GUIMARÃES, J.A.; MENDONÇA, C.L.; GUARANÁ, E.L.S. et al. Estudo retrospectivo de 66 casos de urolitíase obstrutiva em ovinos. Pesqui. Vet. Bras., v.32, p.824-830, 2012.
JONES, M.L.; GIBBONS, P.M.; ROUSEEL, A.J.; DOMINGUEZ, B.J. Mineral composition of uroliths obtained from sheep and goats with obstructive urolithiasis. J. Vet. Intern. Med., v.31, p.1202-1208, 2017.

JONES, M.L.; STREETER, R.N.; GOAD, C.L. Use of dietary cation anion difference for control of urolithiasis risk factors in goats. Am. J. Vet. Res., v.70, p.149-155, 2009.

LAS, J.E.; ODONGO, N.E.; LINDINGER, M.L. et al. Effects of dietary strong acid anion challenge on regulation of acid-base balance in sheep. J. Anim. Sci., v.85, p.2222-2229, 2007.

LIMA, M. B.; MONTEIRO, V.; JORGE, E.M.; CAMPELLO, C.C. Intervalos de referência sanguíneos e a infuência da idade e sexo sobre parâmetros hematológicos e bioquímicos de ovinos da raça Santa Inês criados na Amazônia Oriental. Acta Amaz., v.45, p.317-322, 2015.

LORETTI, A. et al. Clinical and pathological study of an outbreak of obstructive urolithiasis in feedlot cattle in southern Brazil. SciELO Brasil, 2003.

MACLEAY, J. M.; OLIVEIRA, C.E.F.; DAVID, L.O.D. Dietary-induced metabolic acidosis decreases bonemineral density in mature ovariectomized ewes. Calcif. Tissue Int., v.75, p.431-437, 2004.

MAVANGIRA, V.; CORNISH, J.M.; ANGELOS, J.A. Effect of ammonium chloride supplementation on urine $\mathrm{pH}$ and urinary fractional excretion of electrolytes in goats. $J$. Am. Vet. Med. Assoc., v.237, p.1299-1304, 2010.

ORTOLANI, E.L. Diagnóstico e tratamento de alterações ácido-básicas em ruminantes. In: SIMPÓSIO DE PATOLOGIA CLÍNICA VETERINÁRIA., 2003, Porto Alegre. Anais... Porto Alegre, 2003. v.1, p.17-28.

PUGH, D.G.; BAIRD, A.N. Sheep and goat medicine. Philadeplphia: Elsevier, 2012. 640p.

RADOSTITS O.M., GAY C.C.; BLOOD. D.C. et al. Clínica veterinária: um tratado de doenças de bovinos, ovinos, caprinos, suínos e equiídeos. 9.ed. Rio de Janeiro: Guanabara Koogan, 2000. $1737 \mathrm{p}$.

RIET-CORREA, F.; SIMÕES, S.V.D.; VASCONCELOS, J.S. Urolitíase em caprinos e ovinos. Pesqui. Vet. Bras., v.28, p.319-322, 2008. 
SCOTT, P. Transabdominal ultrasonographic examination of 26 Sheep with suspected urinary tract disease (2010-2012). J. Vet. Sci. Med. Diag., v.2, n.1, 2013.

SINGH, T.; AMARPAL, A.; KINJAVDEKAR, P.; AITHAL, H.P. Blood acid-base and electrolyte changes following oral administration of ammonium chloride in goats suffering from obstructive urolithiasis. Indian J. Anim. Sci., v.77, p.745-748, 2007.

SMITH, B.P. Medicina interna de grandes animais. 3.ed. São Paulo: Manole, 2006. 1784p.
STEWART, S.R.; EMERICK, R.J.; PRITCHARD, R.H. Effects of dietary ammonium chloride and variations in calcium to phosphorus ratio on silica urolithiasis in sheep. $J$. Anim. Sci., v.69, p.2225-2229, 1991.

STEWART, S.R.; EMERICK, R.J.; PRITCHARD, R.H. High dietary calcium to phosphorus ratio and alkali-forming potential as factors promoting silica urolithiasis in sheep. $J$. Anim. Sci., v.68, p.498-503, 1990.

STRATTON-PHELPS, M.; HOUSE, J.K. Effect of a commercial anion dietary supplement on acid-base balance, urine volume, and urinary ion excretion in male goats fed oat or grass hay diets. Am. J. Vet. Res., v.65, p.1391-1397, 2004. 